\title{
Confucius in Western Cockpits: The Investigation of Long-Term Versus Short-Term Orientation Culture and Aviation Accidents
}

\author{
Wen-Chin Li and Don Harris \\ Department of Human Factors, Cranfield University, \\ Bedfordshire, United Kingdom \\ \{w.li.2002,d.harris\}@cranfield.ac.uk
}

\begin{abstract}
This research applies the Human Factors Analysis and Classification System and Hofsted's fifth dimension of national culture (Confucian- long-term versus short-term orientation) to compare accident patterns between the US and Taiwan. Asia and Africa have higher accident rates than Europe or America. There are also fundamental differences between Chinese and Western minds. These variations suggest that there should be fundamental, underlying factors causing these differences. Several studies have investigated the relationship between culture and accidents however, no research has investigated Chinese culture and accidents. The findings clearly show different patterns in the human factors causes underlying aviation accidents in these different regions. It could even be argued that the accident analysis system itself has an implicit cultural bias within it, as HFACS was a product of Western culture. Global aviation is strongly influenced by the Western culture, however, the safety challenge is to manage the potential risks it may present.
\end{abstract}

Keywords: Accident Investigation, Confucian, Cross-culture, Human Error, Human Factors Analysis and Classification System.

\section{Introduction}

It is generally acknowledged that the aviation accident rates differ across regions. Asia and Africa have higher accident rates than either Europe or America. These regional variations suggest that there were fundamental, underlying factors causing these differences in accident rates. Furthermore, it can be suggested that the majority of the facets of the aviation system has been constructed from a Western (North American/Western European) perspective (Klein, 2004). As a result, the causal factors underlying accidents and prevention strategies that seem reasonable to Westerners might present problems for East Asian and African people. What is more, Western people might not even be aware of such a problem (Jing, Lu \& Peng, 2001). There has been a great deal of debate about the role of culture in aviation mishaps, however, culture is rarely cited as a causal factor underlying accidents. Nevertheless, culture is 
at the root of action; it underlies the manner by which people communicate and develop attitudes towards life. There are many definitions of culture. A culture is formed by its environment and evolves in response to changes in that environment, therefore, culture and context are really inseparable (Merritt \& Maurino, 2004).

This research applied the Human Factors Analysis and Classification System (Wiegmann \& Shappell, 2003) and Hofsted's (2001) fifth dimension of national culture, Confucian- long-term versus short-term orientation to compare the accident pattern between the US and Taiwan. Confucius's teachings are lessons in practical ethics. People had to rely upon themselves, not some external force, to maintain their humanity. The following are key principles of Confucian teaching, (1) the stability of society is based on unequal relationships between people. These relationship are based on mutual and complementary obligations. Junior owes the senior respect and obedience; the senior owes the junior protection and consideration; (2) the family is the prototype of all social organization. A person is not primarily and individual, harmony is found in the maintenance of everybody's face, in the sense of dignity, selfrespect and prestige; (3) virtuous behaviour toward others consists of not treating others as one would not like to be treated oneself; (4) virtue with regard to one's tasks in life consists of trying to acquire skills and education, working hard, not spending more than necessary, being patient, and persevering, conspicuous consumption is taboo, as is losing one's temper. There are fundamental difference between Chinese minds and Western. In science and technology, Western Truth stimulated analytic thinking, whereas Eastern Virtue led to synthetic thinking (Hofstede, 2001). Through their different logics East and West followed different paths in developing government and in developing science and technology. Whereas the Romans spread the principle of 'government by law', the main continuous principle of Chinese was 'government by man'.

Culture fashions a complex framework of national, organizational and professional attitudes and values within which groups and individuals function. Cultures can be divided into different levels: families, organizations, professions, regions, and countries. The power of culture often goes unrecognized since it represents 'the way we do things here'. It is the natural and unquestioned mode of viewing the world and national cultural characteristics play a significant part in aviation safety (Helmreich \& Merritt, 1998). There were several studies investigated the relationship of culture and accident pattern (Helmreich \& Merritt, 1998; Johnston, 1993; Merritt \& Maurino, 2004; Orasanu \& Connolly, 1993; Soeters \& Boer. 2000). However, no research illustrated Chinese culture and aviation accident's pattern. There is a raising need for investigating the relationship between Chinese culture and safety of aviation operation, as the both of Chinese population and market for aviation industry. To summarize, there is an ongoing need to understand the influence of culture on aviation safety. Detailed examination of the relative incidence of the underlying human factors components in the causation of accidents using HFACS will provide greater insight in this respect, supplementing and adding explanatory power to the observation that accident rates differ between different countries and cultures. This research examines 
the relative frequency of contributory factors using the HFACS framework from aircraft accidents in Taiwan (Chinese culture) and the USA, and relates these differences to aspects of regional culture as described using the typology proposed by Hofstede (1991 \& 2001).

\section{Method}

Data: The data analyzed in the present study are taken from two researches classifying aviation mishaps using the HFACS framework. These are from Taiwan and the USA. There were 523 accidents with 1,762 instances of human error categorized using the HFACS framework from data elicited from the Taiwan Air Force between 1978 and 2002 (Li \& Harris, 2005); and 119 accidents with 319 of categorized instanced of human error in US data recorded between 1990 and 1996 (Wiegmann \& Shappell, 2001). According to Hofstede's (1991 \& 2001) fifth culture dimension, Confucian (long-term versus short-term orientation), the score of Taiwan is 87, the score of US is 29 , the world average is 45 . It is clear that Taiwan is long-term orientation culture, US is short-term orientation culture. It is hypothesized that different cultures will show different patterns in the underlying causal factors in aircraft accidents.

Classification framework: This study based on the HFACS framework as described in Wiegmann \& Shappell (2003). The first level of HFACS categorizes is 'unsafe acts of operators' that can lead to an accident including and comprises of four subcategories of 'decision errors'; 'skill-based errors'; 'perceptual errors' and 'violations' . The second level of HFACS concerns 'preconditions for unsafe acts' which has a further seven sub-categories of 'adverse mental states'; 'adverse physiological states'; 'physical/mental limitations'; 'crew resource management'; 'personal readiness'; 'physical environment', and 'technological environment'. The third level of HFACS is 'unsafe supervision' including 'inadequate supervision'; 'planned inappropriate operation'; 'failure to correct known problem', and 'supervisory violation'. The fourth and highest level of HFACS is 'organizational influences' and comprises of the subcategories of 'resource management'; 'organizational climate' and 'organizational process'.

To avoid over-representation from any single accident, each HFACS category was counted a maximum of only once per accident. These counts acted simply as an indicator of presence or absence of each of the 18 categories in any given accident. These data were then subject to chi-square $\left(\chi^{2}\right)$ analyses to measure the statistical strength of association between HFACS category and country.

Reliability of HFACS Framework: Inter-rater reliabilities of the data from Taiwan, calculated as a simple percentage rate of agreement, obtained reliability figures for the 18 categories of HFACS of between $72.3 \%$ and $96.4 \%$ (2005). The average of the inter-rater reliabilities of the data gathered from the US data showed $76 \%$ (2001). 
Table 1. The Frequency of HFACS Categories Between Taiwan and USA

\begin{tabular}{|c|c|c|c|c|c|}
\hline HFACS Categories & Yes & No & Ye & No & $\begin{array}{c}\text { Chi-square }\left(\chi^{2}\right) \text { and Goodman } \\
\text { \& Kruskal Tau }(\tau)\end{array}$ \\
\hline $\begin{array}{l}\text { Level-4, Organizational } \\
\text { process }\end{array}$ & $\begin{array}{l}76 \\
80\end{array}$ & $\begin{array}{l}447 \\
443\end{array}$ & $\begin{array}{l}10 \\
18\end{array}$ & $\begin{array}{l}109 \\
100\end{array}$ & $\chi^{2}=3.13, \mathrm{df}=1, \mathrm{p}=.076$ \\
\hline Organizational climate & $\begin{array}{l}4 \\
7\end{array}$ & $\begin{array}{l}519 \\
516\end{array}$ & $\begin{array}{l}0 \\
2\end{array}$ & $\begin{array}{l}119 \\
117\end{array}$ & $\chi^{2}=0.91, \mathrm{df}=1, \mathrm{p}=.338$ \\
\hline Resource management & $\begin{array}{l}184 \\
156\end{array}$ & $\begin{array}{l}339 \\
366 \\
\end{array}$ & \begin{tabular}{c|}
3 \\
36
\end{tabular} & $\begin{array}{c}116 \\
83\end{array}$ & $\chi^{2}=50.09, \mathrm{df}=1, \mathrm{p}=.000$ \\
\hline \begin{tabular}{|lr}
$\begin{array}{r}\text { Level-3, } \\
\text { violation }\end{array}$ & Supervisory \\
\end{tabular} & $\begin{array}{l}8 \\
9 \\
\end{array}$ & $\begin{array}{l}515 \\
514 \\
\end{array}$ & $\begin{array}{l}2 \\
2 \\
\end{array}$ & $\begin{array}{l}117 \\
117 \\
\end{array}$ & $\chi^{2}=0.01, \mathrm{df}=1, \mathrm{p}=.904$ \\
\hline $\begin{array}{l}\text { Failed correct a known } \\
\text { problem }\end{array}$ & $\begin{array}{l}12 \\
12\end{array}$ & $\begin{array}{l}511 \\
511\end{array}$ & $\begin{array}{l}2 \\
3\end{array}$ & $\begin{array}{l}117 \\
116\end{array}$ & $\chi^{2}=0.17, d f=1, p=.679$ \\
\hline $\begin{array}{l}\text { Planned } \\
\text { inadequate operations }\end{array}$ & $\begin{array}{l}24 \\
22\end{array}$ & $\begin{array}{l}499 \\
501\end{array}$ & $\begin{array}{l}1 \\
5\end{array}$ & $\begin{array}{l}118 \\
114\end{array}$ & $\chi^{2}=3.64, d f=1, p=.056$ \\
\hline \begin{tabular}{|l} 
Inadequate \\
supervision \\
\end{tabular} & $\begin{array}{l}177 \\
144 \\
\end{array}$ & $\begin{array}{l}346 \\
379 \\
\end{array}$ & $\begin{array}{c}6 \\
33 \\
\end{array}$ & $\begin{array}{c}113 \\
86\end{array}$ & $\chi^{2}=39.45, \mathrm{df}=1, \mathrm{p}=.000$ \\
\hline \begin{tabular}{|c} 
Level-2, \\
environment
\end{tabular} & $\begin{array}{l}44 \\
\text { na }\end{array}$ & $\begin{array}{c}479 \\
\text { na }\end{array}$ & $\begin{array}{l}\text { na } \\
\text { na }\end{array}$ & $\begin{array}{l}\text { na } \\
\text { na }\end{array}$ & na \\
\hline Physical environment & $\begin{array}{l}74 \\
\text { na }\end{array}$ & $\begin{array}{c}449 \\
\text { na }\end{array}$ & $\begin{array}{l}\text { na } \\
\text { na }\end{array}$ & $\begin{array}{l}\text { na } \\
\text { na }\end{array}$ & na \\
\hline Personal readiness & $\begin{array}{l}29 \\
25 \\
\end{array}$ & $\begin{array}{l}494 \\
498 \\
\end{array}$ & $\begin{array}{l}0 \\
6 \\
\end{array}$ & $\begin{array}{l}119 \\
113 \\
\end{array}$ & $\chi^{2}=6.91, \mathrm{df}=1, \mathrm{p}=.008$ \\
\hline $\begin{array}{c}\text { Crew resource } \\
\text { management }\end{array}$ & $\begin{array}{l}146 \\
142 \\
\end{array}$ & $\begin{array}{l}377 \\
381 \\
\end{array}$ & $\begin{array}{l}35 \\
32\end{array}$ & $\begin{array}{l}84 \\
87\end{array}$ & $\chi^{2}=0.10, \mathrm{df}=2, \mathrm{p}=.743$ \\
\hline $\begin{array}{c}\text { Physical } / \text { mental } \\
\text { limitation }\end{array}$ & $\begin{array}{l}73 \\
77 \\
\end{array}$ & $\begin{array}{l}450 \\
446 \\
\end{array}$ & $\begin{array}{l}13 \\
17 \\
\end{array}$ & $\begin{array}{l}106 \\
102\end{array}$ & $\chi^{2}=0.76, d f=1, p=.380$ \\
\hline $\begin{array}{c}\text { Adverse physiological } \\
\text { states }\end{array}$ & $\begin{array}{l}2 \\
5\end{array}$ & $\begin{array}{l}521 \\
518 \\
\end{array}$ & $\begin{array}{l}2 \\
1 \\
\end{array}$ & $\begin{array}{l}117 \\
118 \\
\end{array}$ & $\chi^{2}=2.63, \mathrm{df}=1, \mathrm{p}=.104$ \\
\hline Adverse mental states & $\begin{array}{l}184 \\
156 \\
\end{array}$ & $\begin{array}{l}339 \\
367 \\
\end{array}$ & $\begin{array}{l}16 \\
36 \\
\end{array}$ & $\begin{array}{c}103 \\
83\end{array}$ & $\chi^{2}=21.35, \mathrm{df}=1, \mathrm{p}=.000$ \\
\hline Level-1, Violations & $\begin{array}{l}160 \\
158 \\
\end{array}$ & $\begin{array}{l}363 \\
365 \\
\end{array}$ & $\begin{array}{l}32 \\
36\end{array}$ & $\begin{array}{l}87 \\
83 \\
\end{array}$ & $\chi^{2}=0.63, d f=1, p=.426$ \\
\hline Perceptual errors & $\begin{array}{l}116 \\
106 \\
\end{array}$ & $\begin{array}{l}407 \\
417 \\
\end{array}$ & $\begin{array}{l}17 \\
24 \\
\end{array}$ & $\begin{array}{c}102 \\
95\end{array}$ & $\chi^{2}=3.67, \mathrm{df}=1, \mathrm{p}=.055$ \\
\hline Skilled-based errors & $\begin{array}{l}226 \\
245 \\
\end{array}$ & $\begin{array}{l}297 \\
278 \\
\end{array}$ & $\begin{array}{l}72 \\
56\end{array}$ & $\begin{array}{l}47 \\
63\end{array}$ & $\chi^{2}=11.65, \mathrm{df}=1, \mathrm{p}=.000$ \\
\hline Decision errors & $\begin{array}{l}223 \\
202\end{array}$ & $\begin{array}{l}300 \\
321\end{array}$ & $\begin{array}{l}34 \\
46\end{array}$ & $\begin{array}{l}85 \\
73\end{array}$ & $\chi^{2}=7.99, \mathrm{df}=1, \mathrm{p}=.004$ \\
\hline
\end{tabular}

Note: 1. Numbers show as a Roman font at the top of each cell is the observed value; the numbers shown in an Italic font at the bottom of each cell is the expected value.

2. 'na' indicates no information was available for the categories of 'technology environment' and 'physical environment'.

3. Bold font indicates under-representative.

4. Big size font indicates over-representative. 


\section{Results}

There were six HFACS categories exhibited significant differences in reported frequency of aviation accidents between Taiwan and US (Table 1). These were, 'resource management' (level 4); 'inadequate supervision' (level 3); 'personal readiness' and 'adverse mental states' (level 2); 'skilled-based errors' and 'decision errors' (level 1). Furthermore 'organizational process' (level 4); 'planned inadequate operations' (level 3) and 'perceptual errors' (level 1) were verging on statistical significance $(\mathrm{p}<0.10)$.

Level 4 - Organizational Influences: There was one HFACS category with significant difference between Taiwan and US (table 1). 'Resource management', which includes the selection, staffing and training of human resources at an organizational level, excessive cost cutting, providing unsuitable equipment, and a failure to remedy design flaws, was over-represented in Taiwan and was under-represented in US.

Level 3 - Unsafe Supervision: There was one HFACS category which exhibited significant differences in recorded frequency of being implicated in accidents (table 1). This was 'inadequate supervision' which includes factors such as a failure to provide proper training, adequate rest periods, a lack of accountability, failure to track qualifications and performance, using untrained supervisors and loss of situation awareness at the supervisory level. This category was over-represented in the Taiwan sample and under-represented in the USA.

Level 2 - Preconditions for Unsafe Acts: There were two categories with significant differences in frequency of occurrence between Taiwan and US (table 1). 'Adverse mental states', which includes issues such as over-confidence, stress, loss of situational awareness, distraction, channelized attention and task saturation, was overrepresented in the Taiwan sample, and under-represented in the USA. 'Personal readiness' which encompassed issues associated with inadequate training, selfmedication, poor diet, and overexertion while off duty, was over-represented in frequency of occurrence in Taiwan, and under-represented in US accidents.

Level 1 - Unsafe Acts of Operators: There were two HFACS categories which showed differences in their frequency of occurrence between regions at level-1 (table 1). 'Skill-based errors' which includes actions such as inappropriate stick and rudder coordination, excessive use of flight controls, glide path not maintained, and adopting an improper airspeed or altitude, was over-represent in US accidents but underrepresented in the sample from Taiwan. 'Decision errors', which includes issues such as selecting inappropriate strategies to perform a mission, improper in-flight planning, making an inappropriate decision to abort a take-off or landing or using improper remedial actions in an emergency, was over-represented in Taiwan sample and underrepresented in the US.

\section{Discussion}

When Western (North American/Western European) engineers and human factor specialists develop equipment, training and procedures, they incorporate their own vision of the world which is heavily influenced by the cultural norms of their country. 
They implicitly assume that all users around the world will share their reasoning and values. Klein (2004) observed that people from different nations differ in their cognition in ways that result in dissimilar perceptions, judgments and decision-making. National culture provides a fundamental basis for a group member's behavior, social roles and cognitive processes. It also provides underlying rules about safety, effective communication, and provides the basis for verbal and nonverbal interactions. This research, using the HFACS framework suggests that there are statistically significant differences in the relative frequencies of the underlying human factors causes in aviation mishap between Taiwan and US. However, such a simple analysis alone showing differences between regions has little explanatory power. It is essential to identify the potential causal roots for these differences in relative frequency of the underlying factors in these aviation mishaps.

According to Hofstede's (2001) fifth dimension of national cultures, long-term versus short-term orientation, was found to be based on items reminiscent of the teachings of Confucius, on both of its poles: persistence and thrift to personal stability and respect for tradition. The US culture has strong desire searching for truth and governed by 'law'. The Chinese tradition does not hold laws and abstract principles in high regard and governed by 'man'. This could possibly explain the Taiwan with higher accident rate in 'resource management' (level-4) than US. Furthermore, Western culture believed in absolute guidelines about good and evil, Chinese culture believed what is good and evil depends on the circumstances. It might illustrated the US data has lower accident rate at the category of 'inadequate supervision' (level-3) than Taiwan. The supervisory levels in Taiwan were not following strict principles to perform their duties caused problems. The cultural difference of 'probabilistic thinking of Western' with 'either full or no confidence of Chinese' might describe the US with lower 'adverse mental states' (level-2) accidents than Taiwan. The attitude of overconfidence or no confidence in long-tern orientation culture was not a safe condition for conducting flight operations. Also, the 'perseverance' in long-term orientation culture undermined precondition for unsafe acts and caused higher 'personal readiness' problem (level-2) in Taiwan than US.

Accidents in the US sample are only over-represented at level-1 'unsafe acts of operators' (with over-representation in the 'skilled-based errors' category). It may be suggested that the explanation for these observations is that the US has a culture which prefers individual decision making and responsibility for the self. In Hofstede's (1991) terms it is an ego-oriented society. Chinese place less value on 'cognitive consistency'. Also, it has been shown that in comparison with the US, Chinese view 'disagreement' as less face-threatening to personal relationships than 'injury' or 'disappointment'. A different opinion does not affect their egos so much. Through their different logics East and West followed different paths in developing government and in developing science and technology. In science and technology, Western Truth stimulated analytic thinking, whereas Eastern Virtue led to synthetic thinking (Hofstede, 2001). This cultural characteristic illustrated Taiwan with higher 'decision errors' (level-1) than the US. The analytic thinking approach is a safer approach than synthetic thinking in aviation domain. 


\section{Conclusion}

The findings clearly show different patterns in the human factors causes underlying aviation accidents in different regions. The underlying cultural causes of these differences are also postulated. It should be noted, however, that the USA and Taiwan are only exemplars of the cultures that they represent. Generally the short-term orientation culture seems to be superior for promoting aviation safety compared to the longterm orientation cultures. However factors such as the design of the aircraft, the management procedures and the nature of safety regulation all have a strong Western influence of short-term orientation culture. All of these factors are culturally congruent with the USA, so it is perhaps not too surprising that this country comes out best when using the HFACS to analyze the underlying causes of accidents. It could even be argued that the accident analysis system itself has an implicit cultural bias within it, as HFACS also created by Western culture. Global aviation is strongly influenced by the Western culture, however, the challenge for safety is not to ignore these crosscultural issues influencing safety but to manage the potential risks they may present.

\section{References}

1. Helmreich, R.L., Merritt, A.C.: Culture at Work in Aviation and Medicine: National, Organizational and Professional Influences, Ashgate, Aldershot, England (1998)

2. Hofstede, G.: Culture's Consequences: Comparing Values, Behaviors, Institutions, and Organizations Across Nations. Sage Publications, California (2001)

3. Hofstede, G.: Cultures and Organizations: Software of the Mind. McGraw-Hill, London (1991)

4. Jing, H.S., Lu, C.J., Peng, S.J.: Culture, Authoritarianism and Commercial Aircraft Accident. Human Factors and Aerospace Safety 1(4), 341-359 (2001)

5. Johnston, N.: Regional and Cross-Cultural Aspects of CRM. In: Hayward, B.J., Lowe, A.R. (eds.) Australian Aviation Psychology Symposium, Sydney (1993)

6. Klein, H.A.: Cultural differences in cognition: Barriers in multinational collaborations. In: Montgomery, H.E., Lipshitz, R.E. (eds.) How professionals make decisions, pp. 243-253. Lawrence Erlbaum, Mahwah (2005)

7. Li, W.C., Harris, D.: HFACS Analysis of ROC Air Force Aviation Accidents: reliability analysis and cross-cultural comparison. International Journal of Applied Aviation Studies 5(1) (2005)

8. Merritt, A., Maurino, D.: Cross-cultural factors in aviation safety. In: Kaplan, M. (ed.) Advances in human performance and cognitive engineering research, pp. 147-181. Elsevier, Amsterdam (2004)

9. Orasanu, J., Connolly, T.: The Reinvention of Decision Making. In: Klein, G.A., Orasanu, J., Calderwood, R., Zsambok, C.E. (eds.) Decision Making in Action: Models and Methods, pp. 3-20. Ablex, Norwood, New Jersey (1993)

10. Soeters, J.L., Boer, P.C.: Culture and flight safety in military aviation. The. International Journal of Aviation Psychology 10(2), 111-133 (2000)

11. Wiegmann, D.A., Shappell, S.A.: Human Error Analysis of Commerical Aviation Accidents: Application of the Human Factors Analysis and Classification System. Aviation, Space, and Environmental Medicine 72(11), 1006-1016 (2001c)

12. Wiegmann, D.A., Shappell, S.A.: A Human Error Approach to Aviation Accident Analysis: The Human Factors Analysis and Classification System, Ashgate, Aldershot, England (2003) 